\title{
Effect of nutritional and growth hormonal factors on in vitro regeneration of papaya (Carica papaya L. Cv. Red Lady)
}

\author{
Van-Hong Nguyen ${ }^{1}$, Chung-Ruey Yen ${ }^{2}$ and Ching-Hsiang Hsieh ${ }^{2 *}$ \\ ${ }^{1}$ Department of Tropical Agriculture and International Cooperation, National Pingtung University of Science and Technology, Pingtung 91201, \\ Taiwan (R.O.C). \\ ${ }^{2}$ Department of Plant Industry, National Pingtung University of Science and Technology, Pingtung 91201, Taiwan (R.O.C).
}

\begin{abstract}
An efficient in vitro regeneration system was developed for the hermaphrodite papaya 'Red Lady' using nodal explants. Nodal explants were cultured on modified Murashige and Skoog (MS) medium supplemented with 3 6-benzylaminopurine (BAP) concentrations (0.0, 0.5 and $\left.1.0 \mathrm{mgL}^{-1}\right)$ or kinetin $\left(10 \mathrm{mgL}^{-1}\right)$ in combination with 1-naphthaleneacetic acid (NAA) $\left(0.0,0.1,0.3,0.4\right.$ and $\left.0.5 \mathrm{mgL}^{-1}\right)$. Media consisted of 0.5 or $1.0 \mathrm{mgL}^{-1} \mathrm{BAP}$ in combination with $0.1 \mathrm{mgL}^{-1}$ NAA were determined to be the most effective based on the percentage of explants that produced shoots (93.33 and $86.67 \%$, respectively), mean number of shoots (1.79 and 1.81 shoots, respectively) and shoot height $(2.26$ and $1.95 \mathrm{~mm}$, respectively). Shoot multiplication and elongation was achieved 30 days after transferring the initiated shoots to full-strength MS supplemented with $0.5 \mathrm{mgL}^{-1} \mathrm{BAP}, 0.1 \mathrm{mgL}^{-1} \mathrm{NAA}$, and $200-400 \mathrm{mgL}^{-1}$ casein hydrolysate $(\mathrm{CH})$. Effect of full and haft-strength MS medium supplemented with different indole3-butyric acid (IBA) concentrations $\left(0.0-4.0 \mathrm{mgL}^{-1}\right)$ was tested for rooting. Adventitious rooting occurred after subculturing excised shoots on a medium containing 2.0 or $2.5 \mathrm{mgL}^{-1} \mathrm{IBA}$ and $300 \mathrm{mgL}^{-1} \mathrm{CH}$, and plantlets were successfully acclimatised on potting medium consisting of peat moss: perlite (1:1). After 40 days of acclimatisation, plantlets grew normally and vigorously. This protocol can be used for commercial production of 'Red Lady' papaya plantlets.
\end{abstract}

Keywords: 1-naphthaleneacetic acid, 6-benzylaminopurine, casein hydrolysate, indole-3-butyric acid, MS medium.

\section{INTRODUCTION}

Papaya (Carica papaya L.) is a polygamous species with three forms of inflorescences: male, female and hermaphrodite (Paull \& Duarte, 2011). It is one of the few fruit crops still propagated mainly by seeds. Inherent heterozygosity, production of non-true-to-types and susceptibility to papaya ring spot virus are some problems which hindered the propagation of papaya by seeds (Teixeira da Silva et al., 2007; Clarindo et al., 2008). It was also reported that undesirable male plants, which are useless, prevail as high as $30 \%$ and sometimes over $50 \%$ of trees planted from seeds in papaya fields (Jordan et al., 1983). In addition, plants grown from seeds show considerable variation in disease susceptibility, fruit quality and yield (Teixeira da Silva et al., 2007).

The possibility of developing planting materials, which are highly productive and resistant to diseases with similar characteristics of the papaya mother plants through asexual propagation has been reported (San Jose \& Marim, 1988). Conventional asexual propagation techniques, such as rooting of cutting and grafting have been successful (Ramkhelawan \& Baksh, 1998; Chong et al., 2008). However, they are often tedious and impractical to be carried out on large scale due to the limited number of plants produced by mother plant (Setargie et al., 2015). In addition, these methods cannot be used to exclude transmission of systemic diseases from mother plants. Micropropagation represents an economic way of continuously producing new uniform true-to-parental type planting materials of known superior lines (Roy et al., 2012; Mumo et al., 2013).

*Corresponding author (hsieh@mail.npust.edu.tw; iD https://orcid.org/0000-0002-7764-6497) 
In vitro propagation techniques can be employed to produce a large number of true-to-type high-quality planting material in papaya cultivation. Furthermore, the techniques can be used as an important tool in crop improvement programmes since they help to overcome problems experienced in conventional breeding methods and lead to rapid clonal production of crops.

Several studies on in vitro propagation of different papaya cultivars using explants with seedling origin (Ascencio-Cabral et al., 2008; Farzana et al., 2008) as well as from asexual organs (Winnaar, 1988; Kabir et al., 2007; Panjaitan et al., 2007; Teixeira da Silva et al., 2007; Wu et al., 2012; Ambasta \& Kumari, 2013; Setargie et al., 2015) have been reported. However, the stages of in vitro propagation of papaya respond differently to variation of explants, genotype of explants as well as nutritional and hormonal composition of the medium (Winnaar, 1988; Usman et al., 2002; Mumo et al., 2013). Therefore, suitable protocols have to be established for different papaya varieties and relevant explants used. 'Red Lady', a hybrid papaya variety, is one of the newly imported cultivars growing in Taiwan and propagated using seeds. Only a small percentage of plantlets used are derived from grafting and cutting methods. Application of in vitro propagation technique to produce 'Red Lady' plantlets from nodal segments has not been reported and applied in practice. The present study was conducted to determine the effects of growth regulators, casein and medium composition on in vitro propagation of 'Red Lady' papaya from nodal segments.

\section{METHODOLOGY}

\section{Plant materials and sterilisation procedure}

Newly developed shoot sprouts of $5-10 \mathrm{~cm}$ were collected from a hermaphrodite 'Red Lady' papaya cultivar growing in a greenhouse. After removing the leaves explants were washed under running tap water for $1 \mathrm{~h}$ and taken into the laboratory. Subsequently, lateral buds were sterilised by immersing in $70 \%$ ethanol for $30 \mathrm{~s}$ followed by treating with $20 \%$ clolox solution containing 10 drops $\mathrm{L}^{-1}$ of tween-20 (sigma, USA) for $15 \mathrm{~min}$. Finally, explants were rinsed 5 times with sterile distilled water, damaged parts removed and separated into single nodal segments (6 mm long) before culturing on MS medium containing $30 \mathrm{gL}^{-1}$ sucrose and $0.65 \%$ agar $(\mathrm{w} / \mathrm{v})$. Twenty days after culture establishment uncontaminated explants were transferred on to shoot induction medium.

\section{Shoot induction}

Uncontaminated explants were cultured on MS medium (Murashige \& Skoog, 1962) supplemented with $6.5 \mathrm{gL}^{-1}$ agar, $30 \mathrm{gL}^{-1}$ sucrose and 6-benzylaminopurine (BAP: $\left.0,0.5,1.0 \mathrm{mgL}^{-1}\right)$, or kinetin $\left(10 \mathrm{mgL}^{-1}\right)$, alone or in combination with 1-naphthaleneacetic acid (NAA: 0.1, $0.2,0.3,0.4$, or $\left.0.5 \mathrm{mgL}^{-1}\right)$. The experiment was replicated 5 times. Each treatment consisted of 12 explants per replicate.

\section{Multiplication and elongation of shoot}

Regenerated shoots from 40-day old cultures of MS $+\operatorname{BAP}\left(1.0 \mathrm{mgL}^{-1}\right)+\mathrm{NAA}\left(0.1 \mathrm{mgL}^{-1}\right)$ at the shoot induction step were trimmed to shoots that were $0.5 \mathrm{~cm}$ long with 3 leaves, and were subcultured on to MS basal media supplemented with $6.5 \mathrm{gL}^{-1}$ agar, $30 \mathrm{gL}^{-1}$ sucrose, and BAP only $\left(0.0,0.5\right.$ and $\left.1.0 \mathrm{mgL}^{-1}\right)$ or BAP $(0.5$ and $\left.1.0 \mathrm{mgL}^{-1}\right)$ in combination with NAA $(0.1,0.2,0.3,0.4$ and $\left.0.5 \mathrm{mgL}^{-1}\right)$ for shoot multiplication and elongation.

Small $(0.5 \mathrm{~cm}, 3$ leaves $)$ individual shoots from 40-day cultures of MS + BAP $\left(0.5 \mathrm{mgL}^{-1}\right)+$ NAA $\left(0.1 \mathrm{mgL}^{-1}\right)$ were excised carefully and transferred to a medium containing MS basal medium, agar $\left(6.5 \mathrm{gL}^{-1}\right)$, sucrose $\left(30 \mathrm{gL}^{-1}\right)$, BAP $\left(0.5 \mathrm{mgL}^{-1}\right)$, NAA $\left(0.2 \mathrm{mgL}^{-1}\right)$ (Sign: MSC), and different concentrations of casein hydrolysate (CH) (Merck, Germany) (0, 50, 100, 200, 300,400 , and $\left.500 \mathrm{mgL}^{-1}\right)$ to determine the effects of $\mathrm{CH}$ on elongation and multiplication of shoot. The experiment was replicated 5 times. Each treatment consisted of 6 explants per replicate.

\section{Rooting of shoot}

Shoots (length of $1.5 \mathrm{~cm}$ ) from 30-day old cultures in MSC medium with $\mathrm{CH}\left(300 \mathrm{mgL}^{-1}\right)$ were separated individually and transferred to rooting media containing full and half-strength $\mathrm{MS}$ salts supplemented with agar $\left(6.5 \mathrm{gL}^{-1}\right)$, sucrose $\left(30 \mathrm{gL}^{-1}\right), \mathrm{CH}\left(300 \mathrm{mgL}^{-1}\right)$, and different concentrations of indole-3-butyric acid (IBA: $0.0,0.5,1.0,1.5,2.0,2.5,3.0,3.5$, or $\left.4.0 \mathrm{mgL}^{-1}\right)$. The experiment was replicated 5 times. Each treatment consisted of 6 explants per replicate.

\section{Culture conditions and statistical analysis}

Cultures were incubated at $25 \pm 2{ }^{\circ} \mathrm{C}$ with $16 \mathrm{~h} / 8 \mathrm{~h}$ of day/night under a cool white fluorescent light delivering approximately $45 \mu \mathrm{mol} \mathrm{m} \mathrm{m}^{-2} \mathrm{~s}^{-1}$. The research was carried out in the Exploration and Development of Potential 
Ornamental Plant Material Laboratory, Department of Plant Industry, National Pingtung University of Science and Technology, Taiwan from February 2015 to February 2017.

All experiments were arranged as completely randomised designs. Data were analysed using one-way ANOVA for shoot initiation, shoot proliferation and acclimatisation or two-way ANOVA for shoot rooting, and when F-test showed significant treatment results, separation of treatment means were determined using Duncan's multiple range test (DMRT) at $\mathrm{p}<0.01$.

\section{RESULTS AND DISCUSSION}

\section{Shoot induction}

In this study, nodal explants were responsive to all treatments tested with or without plant growth regulators (PGR) indicating the high regenerative potential of nodal explants. Shoot regeneration began at week 3 of culture with visible proliferation of buds from the nodes (Figure1 A, B). Results of in vitro shoot regeneration from single

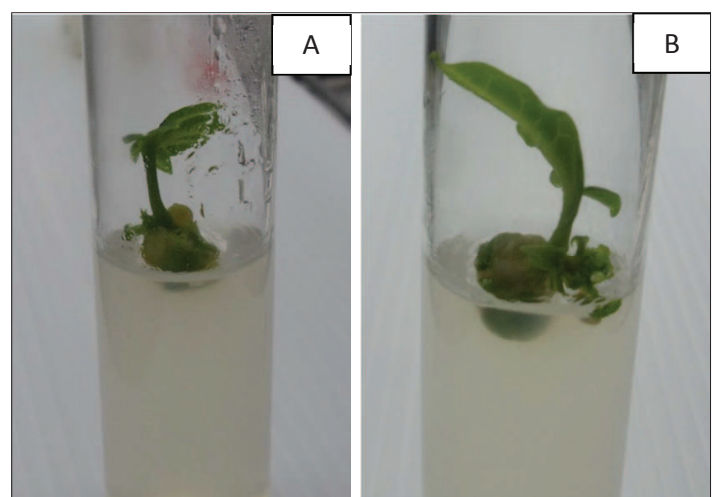

Figure 1: Shoot induction from nodal explants of papaya. (A) shoot regeneration began by week 3 of culture; (B) proliferation of shoot from the node of the explants in $\mathrm{MS}+\mathrm{BAP}\left(1.0 \mathrm{mgL}^{-1}\right)+\mathrm{NAA}\left(0.1 \mathrm{mgL}^{-1}\right)$.

node explants exposed to different PGR concentrations after 40 days of culture are shown in Table 1. MS media devoid of PGR or high NAA concentration in combination with BAP showed the lowest response of shoot initiation. Shoot regeneration from node explants cultured on MS

Table 1: Effect of BAP, kinetin in combination with NAA in MS medium on shoot induction from nodal explants of papaya (after 40 days of culture)

\begin{tabular}{cccccc}
\hline $\begin{array}{c}\text { Growth regulators }\left(\mathrm{mgL}^{-1}\right) \\
\text { BAP }\end{array}$ & Kinetin & NAA & $\begin{array}{c}\text { Percentage of } \\
\text { explants produced } \\
\text { shoots }(\text { mean } \pm \text { SE) }\end{array}$ & $\begin{array}{c}\text { Mean number of } \\
\text { shoots }(\text { mean } \pm \text { SE) }\end{array}$ & $\begin{array}{c}\text { Shoot height }(\mathrm{mm}) \\
\text { (mean } \pm \mathrm{SE})\end{array}$ \\
\hline 0.0 & & 0.0 & $6.67 \pm 3.73 \mathrm{~h}$ & $0.40 \pm 0.55 \mathrm{~d}$ & $0.70 \pm 0.97 \mathrm{hi}$ \\
0.5 & & 0.0 & $43.33 \pm 3.73 \mathrm{ef}$ & $1.00 \pm 0.00 \mathrm{c}$ & $2.11 \pm 0.67 \mathrm{abc}$ \\
1.0 & & 0.0 & $53.33 \pm 4.56 \mathrm{de}$ & $1.00 \pm 0.00 \mathrm{c}$ & $2.14 \pm 0.25 \mathrm{ab}$ \\
0.5 & & 0.1 & $93.33 \pm 3.73 \mathrm{a}$ & $1.79 \pm 0.16 \mathrm{a}$ & $2.24 \pm 0.28 \mathrm{a}$ \\
1.0 & & 0.1 & $86.67 \pm 4.56 \mathrm{a}$ & $1.81 \pm 0.18 \mathrm{a}$ & $1.95 \pm 0.08 \mathrm{abcde}$ \\
0.5 & & 0.2 & $60.00 \pm 3.73 \mathrm{~cd}$ & $1.30 \pm 0.24 \mathrm{bc}$ & $1.76 \pm 0.06 \mathrm{abcdefg}$ \\
1.0 & & 0.2 & $70.00 \pm 4.56 \mathrm{bc}$ & $1.34 \pm 0.15 \mathrm{bc}$ & $1.67 \pm 0.12 \mathrm{abcdefg}$ \\
0.5 & & 0.3 & $36.67 \pm 4.56 \mathrm{f}$ & $1.00 \pm 0.00 \mathrm{c}$ & $1.43 \pm 0.15 \mathrm{efg}$ \\
1.0 & & 0.3 & $43.33 \pm 6.97 \mathrm{ef}$ & $1.17 \pm 0.24 \mathrm{bc}$ & $1.48 \pm 0.14 \mathrm{defg}$ \\
0.5 & & 0.4 & $23.33 \pm 3.73 \mathrm{~g}$ & $1.00 \pm 0.00 \mathrm{c}$ & $1.25 \pm 0.19 \mathrm{fgh}$ \\
1.0 & & 0.4 & $23.33 \pm 6.97 \mathrm{~g}$ & $1.00 \pm 0.00 \mathrm{c}$ & $1.20 \pm 0.19 \mathrm{gh}$ \\
0.5 & & 0.5 & $3.33 \pm 4.56 \mathrm{~h}$ & $0.20 \pm 0.45 \mathrm{~d}$ & $0.20 \pm 0.45 \mathrm{i}$ \\
1.0 & & 0.5 & $6.67 \pm 3.73 \mathrm{~h}$ & $0.40 \pm 0.55 \mathrm{~d}$ & $0.44 \pm 0.61 \mathrm{i}$ \\
& 10 & 0.0 & $23.33 \pm 9.13 \mathrm{~g}$ & $1.00 \pm 0.00 \mathrm{c}$ & $1.52 \pm 0.33 \mathrm{cdefg}$ \\
& 10 & 0.1 & $53.33 \pm 7.45 \mathrm{de}$ & $1.52 \pm 0.21 \mathrm{ab}$ & $2.04 \pm 0.10 \mathrm{abcd}$ \\
& 10 & 0.2 & $73.33 \pm 9.13 \mathrm{~b}$ & $1.31 \pm 0.08 \mathrm{bc}$ & $1.82 \pm 0.12 \mathrm{abcdef}$ \\
& 10 & 0.3 & $43.33 \pm 9.13 \mathrm{ef}$ & $1.30 \pm 0.30 \mathrm{bc}$ & $1.65 \pm 0.19 \mathrm{abcdefg}$ \\
& 10 & 0.4 & $40.00 \pm 9.13 \mathrm{f}$ & $1.07 \pm 0.15 \mathrm{c}$ & $1.55 \pm 0.06 \mathrm{bcdefg}$ \\
& 10 & 0.5 & $36.67 \pm 7.45 \mathrm{f}$ & $1.00 \pm 0.00 \mathrm{c}$ & $1.50 \pm 0.20 \mathrm{defg}$ \\
\hline
\end{tabular}

Means followed by the same alphabet are not significantly different based on DMRT (at $p<0.01$ ) 
media supplemented with different combinations of BA $\left(0.5\right.$ or $\left.1.0 \mathrm{mgL}^{-1}\right)$ and NAA $(0.1,0.2,0.3,0.4$ or $\left.0.5 \mathrm{mgL}^{-1}\right)$ was higher compared to media supplemented with $\operatorname{BAP}\left(0.5,1.0 \mathrm{mgL}^{-1}\right)$ alone or $10 \mathrm{mgL}^{-1}$ kinetin in combination with NAA $\left(0,0.1,0.2,0.3,0.4,0.5 \mathrm{mgL}^{-1}\right)$ (Table 1). MS media supplemented with 0.5 or $1.0 \mathrm{mgL}^{-1}$ BAP with $0.1 \mathrm{mgL}^{-1} \mathrm{NAA}$ were the most effective media for regeneration of shoots $(93.33$ and $86.67 \%$, respectively). Similarly, nodal explants cultured on 0.5 or $1.0 \mathrm{mgL}^{-1} \mathrm{BAP}$ in combination with $0.1 \mathrm{mgL}^{-1} \mathrm{NAA}$ produced the highest mean number of shoots (1.79 and 1.81 shoots per node, respectively) with highest shoot elongation ( 2.26 and $1.95 \mathrm{~mm}$, respectively) compared to all the other media tested (Table 1).

In this study, the response of shoot regeneration to combinations of cytokinins (BAP, kinetin) and auxins (NAA) was better compared to the effects of cytokinins (BAP or kinetin) only. This is an evidence for the beneficial effects of the combination of cytokinin and auxin on shoot regeneration as reported earlier for other plants (Suksa-Ard et al., 1997; Sultana \& Bari Miah, 2003) as well as for papaya (Panjaitan et al., 2007; Rohman et al., 2007; Roy et al., 2012; Setargie et al., 2015).

Among the two cytokinins (BAP, Kinetin) tested, BAP in combination with NAA was found to be the best in terms of percentage of explants that produced shoots, mean number of shoots and shoot height, and the medium supplemented with BAP $\left(0.5\right.$ or $\left.1.0 \mathrm{mgL}^{-1}\right)$ and $\operatorname{NAA}\left(0.1 \mathrm{mgL}^{-1}\right)$ was found as the best. The results of the present study agrees with Roy et al. (2012) who reported higher shoot regeneration from lateral buds on media supplemented with BAP $\left(0.5 \mathrm{mgL}^{-1}\right)$ in combination with NAA $\left(0.1 \mathrm{mgL}^{-1}\right)$ compared to BAP or kinetin alone or combinations of kinetin and NAA. Similarly, Winnaar (1988) and Reuveni et al. (1990) reported that MS with $0.5 \mathrm{mgL}^{-1} \mathrm{BA}$ and $0.1 \mathrm{mgL}^{-1} \mathrm{NAA}$ was optimum for regeneration of papaya from lateral bud explants. In contrast, Setargie et al. (2015) reported that combination of BAP $\left(1.0 \mathrm{mg} \mathrm{L}^{-1}\right)$ and NAA $\left(0.5 \mathrm{mg} \mathrm{L}^{-1}\right)$ as the best for regeneration while Rohman et al. (2007) stated it as BAP $\left(0.5 \mathrm{mgL}^{-1}\right)$ and NAA $\left(0.20 \mathrm{mgL}^{-1}\right)$. Thus, the differences observed may be the related response of the genotypes of the plant material used to PGR (Jabeen et al., 2005).

\section{Shoot multiplication and elongation}

\section{Effect of PGR combination on shoot multiplication and elongation}

Supplementing PGR into MS media was advantageous and promoted both shoot multiplication and elongation (Table 2). MS medium without PGR resulted in poor rate of multiplication, shoot length and number of leaves per shoot (1.09 folds, $5.73 \mathrm{~mm}$ and 2.99 leaves, respectively). Incorporation of BAP alone or combination of BAP and

Table 2: Effect of different concentrations of BAP, or combination of BAP and NAA on multiplication and elongation of papaya shoot (after 30 days of culture)

\begin{tabular}{ccccc}
\hline $\begin{array}{c}\text { Growth regulators } \\
\left(\mathrm{mgL}^{-1}\right)\end{array}$ & $\begin{array}{c}\text { Multiplication rate } \\
\text { (folds) } \pm \mathrm{SE}\end{array}$ & $\begin{array}{c}\text { Mean shoot length } \\
(\mathrm{mm}) \pm \mathrm{SE}\end{array}$ & $\begin{array}{c}\text { Mean no. of leaves per } \\
\text { shoot (leaves) } \pm \mathrm{SE}\end{array}$ \\
\hline BAP & NAA & & & \\
\hline 0.0 & 0.0 & $1.09 \pm 0.04 \mathrm{k}$ & $5.73 \pm 0.08 \mathrm{f}$ & $2.99 \pm 0.05 \mathrm{~h}$ \\
0.5 & 0.0 & $3.52 \pm 0.04 \mathrm{e}$ & $5.69 \pm 0.09 \mathrm{f}$ & $3.35 \pm 0.06 \mathrm{f}$ \\
1.0 & 0.0 & $4.37 \pm 0.05 \mathrm{~d}$ & $5.22 \pm 0.05 \mathrm{~g}$ & $3.20 \pm 0.03 \mathrm{~g}$ \\
0.5 & 0.1 & $5.00 \pm 0.04 \mathrm{a}$ & $6.85 \pm 0.05 \mathrm{a}$ & $3.90 \pm 0.03 \mathrm{a}$ \\
0.5 & 0.2 & $4.53 \pm 0.05 \mathrm{c}$ & $6.86 \pm 0.04 \mathrm{a}$ & $3.92 \pm 0.03 \mathrm{a}$ \\
0.5 & 0.3 & $2.86 \pm 0.05 \mathrm{~g}$ & $6.43 \pm 0.07 \mathrm{bc}$ & $3.76 \pm 0.04 \mathrm{c}$ \\
0.5 & 0.4 & $1.99 \pm 0.03 \mathrm{i}$ & $6.22 \pm 0.06 \mathrm{de}$ & $3.66 \pm 0.04 \mathrm{~d}$ \\
0.5 & 0.5 & $1.31 \pm 0.04 \mathrm{j}$ & $5.70 \pm 0.12 \mathrm{f}$ & $3.56 \pm 0.04 \mathrm{e}$ \\
1.0 & 0.1 & $4.71 \pm 0.03 \mathrm{~b}$ & $5.77 \pm 0.07 \mathrm{f}$ & $3.59 \pm 0.04 \mathrm{e}$ \\
1.0 & 0.2 & $4.75 \pm 0.03 \mathrm{~b}$ & $6.50 \pm 0.04 \mathrm{~b}$ & $3.82 \pm 0.02 \mathrm{~b}$ \\
1.0 & 0.3 & $3.34 \pm 0.04 \mathrm{f}$ & $6.34 \pm 0.06 \mathrm{~cd}$ & $3.71 \pm 0.04 \mathrm{~cd}$ \\
1.0 & 0.4 & $2.83 \pm 0.07 \mathrm{~g}$ & $6.12 \pm 0.06 \mathrm{e}$ & $3.71 \pm 0.04 \mathrm{~cd}$ \\
1.0 & 0.5 & $2.07 \pm 0.02 \mathrm{~h}$ & $5.79 \pm 0.08 \mathrm{f}$ & $3.57 \pm 0.05 \mathrm{e}$ \\
\hline
\end{tabular}

Means followed by the same alphabet are not significantly different based on DMRT (at $p<0.01$ ) 
NAA into MS medium increased shoot multiplication (from 1.31 to 5.00 folds), shoot length (from 5.22 to $6.86 \mathrm{~mm}$ ) and number of leaves per shoot (from 3.20 to 3.92 leaves).

MS medium supplemented with BAP $\left(0.5 \mathrm{mgL}^{-1}\right)$ and NAA $\left(0.1 \mathrm{mgL}^{-1}\right)$ was found to be the most effective combination of growth regulators for shoot formation and shoot multiplication (5.00 folds). In addition, best results for shoot length and number of nodes per shoot were achieved in media consisting of combinations of BAP $\left(0.5 \mathrm{mgL}^{-1}\right)+\mathrm{NAA}\left(0.1 \mathrm{mgL}^{-1}\right)$ or BAP $\left(0.5 \mathrm{mgL}^{-1}\right)+$ NAA $\left(0.2 \mathrm{mgL}^{-1}\right)$. Therefore, MS medium supplemented with BAP $\left(0.5 \mathrm{mgL}^{-1}\right)$ and NAA $\left(0.1 \mathrm{mgL}^{-1}\right)$ can be considered as best for elongation and multiplication of shoots.

The ratio of cytokinin and auxin is an important factor for the differentiation of adventitious shoots (Skoog \& Miller, 1957). Furthermore, supply of auxin (NAA) at low concentration to the media containing cytokinin (BAP) enhanced shoot proliferation (Reuveni et al., 1990). Therefore, the combination of BAP and NAA was used at different rates in shoot multiplication of papaya in many previous studies (Anandan et al., 2011; Ambasta \& Kumari, 2013; Mumo et al., 2013). In agreement with these results, use of low NAA concentration $\left(0.1 \mathrm{mgL}^{-1}\right)$ combined with BAP produced better results compared to higher NAA concentration, and the best results of all parameters were achieved when $0.5 \mathrm{mgL}^{-1}$ BAP and $0.1 \mathrm{mgL}^{-1} \mathrm{NAA}$ was incorporated into MS medium. Similar results were reported by Mumo et al. (2013). In contrast, Kabir et al. (2007) achieved the best result of shoot proliferation at higher NAA $\left(0.5 \mathrm{mgL}^{-1}\right)$ concentration in combination with BAP $\left(1.0 \mathrm{mgL}^{-1}\right)$ for papaya variety 'Shahi' showing the interactive effects of genotype and PGR on shoot multiplication.

\section{Effect of casein hydrolysate concentration on elongation and multiplication of shoot}

Although $\mathrm{MS}+\mathrm{BAP}\left(0.5 \mathrm{mgL}^{-1}\right)+\mathrm{NAA}\left(0.1 \mathrm{mgL}^{-1}\right)$ proved very good for healthy shoot proliferation, shoot elongation was not very satisfactory and the maximum shoot length was $6.86 \mathrm{~mm}$ with 3.90 leaves per shoot. To facilitate further shoot multiplication, shoot elongation and increased number of leaves per shoot, individual shoots were transferred to MSC with different concentrations of $\mathrm{CH}$ and the results are shown in Figures 2 and 3.

Data indicated that incorporation of $\mathrm{CH}$ to $\mathrm{MS}$ medium increased shoot elongation as well as shoot multiplication after 30 days of culture (Figure 2)
( $\mathrm{p}<0.01$ ). Incorporation of 200 to $500 \mathrm{mgL}^{-1}$ of $\mathrm{CH}$ increased the shoot multiplication rate significantly in the medium containing $\mathrm{CH}$ compared to the medium without $\mathrm{CH}$. Although shoot multiplication was achieved in MSC with $\mathrm{CH}\left(50 \mathrm{mgL}^{-1}\right)$, the results were not significantly different from MSC without $\mathrm{CH}$.

Furthermore, quality of shoots, shoot length and number of leaves per shoot in all treatments supplemented with $\mathrm{CH}$ was higher than in the treatment without $\mathrm{CH}$ at 30 days of culture (Figure 3). Shoot length increased with the increase of $\mathrm{CH}$ up to $200 \mathrm{mgL}^{-1}$ and thereafter no significant increase in shoot length was observed (Figure 3). A reduction in shoot length was found in both cases when using $500 \mathrm{mgL}^{-1} \mathrm{CH}$ and reducing the $\mathrm{CH}$ concentration to lower than $200 \mathrm{mgL}^{-1}$.

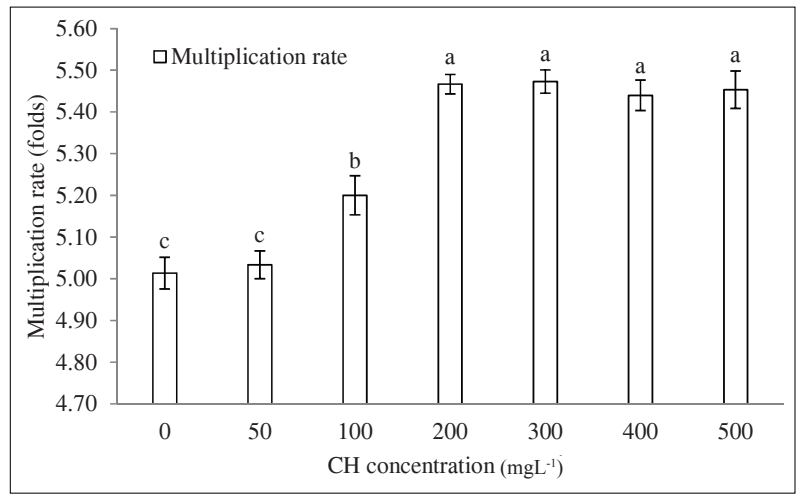

Figure 2: Effect of $\mathrm{CH}$ concentration on rate of multiplication (30 days of subculture). Different letters above bars show significant differences (DMRT, $\mathrm{p}<0.01$ ). Error bars indicate SE.

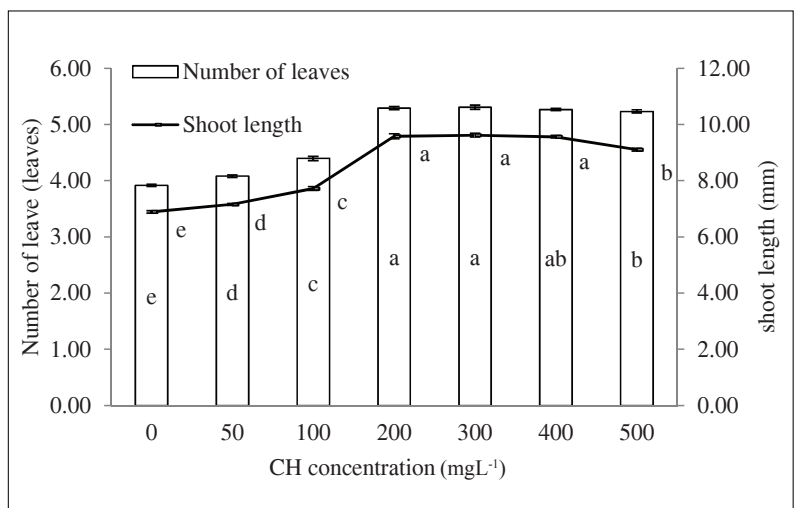

Figure 3: Effect of $\mathrm{CH}$ concentration on length and number of leaves per shoot (after 30 days of subculture). Different letters at centre bars or right lines show significant differences (DMRT, $\mathrm{p}<0.01$ ). Error bars, or line indicate SE. 
Furthermore, the highest number of leaves per shoot was obtained in MSC media containing 200, 300, or $400 \mathrm{mgL}^{-1}$ of $\mathrm{CH}$ compared to the MSC media containing other $\mathrm{CH}$ concentrations $\left(50,100\right.$, or $\left.500 \mathrm{mgL}^{-1}\right)(\mathrm{p}<0.01)$. Considering the best result of all parameters, MSC media containing $\mathrm{CH}$ of 200,300 or $400 \mathrm{mgL}^{-1}$ were recognised as optimum media for elongation and multiplication of shoots. Shoot clusters that developed in these media contained shoots with satisfactory shoot length, number of leaves per shoot as well as leaf shape.

Casein hydrolysate is a source of calcium, phosphate, several microelements, vitamins and most importantly, a mixture of up to 18 amino acids (George \& De Klerk, 2008). Thus, the use of $\mathrm{CH}$ provides complementarily essential nutritional elements, which had been missed in the basal medium. Many authors reported that the use of $\mathrm{CH}$ could improve proliferation of in vitro shoots at the multiplication stage in many genotypes (Cohen \& Cooper, 1982; Gao et al., 2003; Chaturvedi et al., 2004; Sridhar \& Aswath, 2014; Hosny et al., 2016). Prakash et al. (2003) reported that $\mathrm{CH}$ proved inhibitory for shoot differentiation in jojoba. In this study, MSC containing $\mathrm{CH}$ at concentrations of 200,300 or $400 \mathrm{mgL}^{-1}$ were recognised as optimum for shoot proliferation and similar results are reported in Amorpha fruiticosa (Gao et al., 2003) and neem (Chaturvedi et al., 2004). In agreement with the results of the present study, Roy et al. (2012) claimed that addition of $200 \mathrm{mgL}^{-1} \mathrm{CH}$ to the multiplication medium of papaya increased the number of shoots per culture and shoot growth with healthy leaves. In contrast, Chan and Teo (1994) also used 500 $\mathrm{mgL}^{-1} \mathrm{CH}$ for multiple shoots in 'Taiping' papaya.

\section{Rooting of shoots}

Response of papaya shoots to rooting in $1 / 2 \mathrm{MS}$ or MS under different IBA concentrations after 30 days of culture are shown in Table 3. Both MS medium and IBA concentration affect root formation of in vitro shoots significantly $(\mathrm{p}<0.01)$. Although there is no significant differences for percentage of shoots produced roots between 1/2 MS and MS media (Figure 4B), most of the other growth parameters such as number of roots

Table 3: Effect of different IBA concentrations on rooting of papaya shoot cultured on half and full strength MS medium (after 30 days of culture)

\begin{tabular}{cccccc}
\hline $\begin{array}{c}\text { Media } \\
\text { culture }\end{array}$ & $\begin{array}{c}\text { IBA } \\
\text { concentration } \\
\left(\mathrm{mgL}^{-1}\right)\end{array}$ & $\begin{array}{c}\text { Time required for } \\
\text { root formation } \\
(\text { days })\end{array}$ & $\begin{array}{c}\text { Percentage of shoot } \\
\text { produced root } \pm \mathrm{SE}\end{array}$ & $\begin{array}{c}\text { Rooting of shoot } \\
\text { No. of roots } \\
\text { (roots }) \pm \mathrm{SE}\end{array}$ & $\begin{array}{c}\text { Root length } \\
(\mathrm{mm}) \pm \mathrm{SE}\end{array}$ \\
\hline $\mathrm{MS} / 2$ & 0.0 & - & $0.00 \mathrm{j}$ & - & - \\
& 0.5 & $14.90 \pm 0.89 \mathrm{~g}$ & $20.00(26.33) \pm 7.45 \mathrm{i}$ & $1.70 \pm 0.45 \mathrm{f}$ & $28.07 \pm 0.63 \mathrm{~g}$ \\
& 1.0 & $12.33 \pm 0.51 \mathrm{~h}$ & $40.00(39.16) \pm 9.13 \mathrm{~h}$ & $2.43 \pm 0.09 \mathrm{de}$ & $31.42 \pm 0.27 \mathrm{e}$ \\
& 1.5 & $10.82 \pm 0.58 \mathrm{i}$ & $70.00(56.97) \pm 7.45 \mathrm{def}$ & $2.61 \pm 0.23 \mathrm{~cd}$ & $33.56 \pm 0.44 \mathrm{~b}$ \\
& 2.0 & $10.87 \pm 0.18 \mathrm{i}$ & $100.00(90.00) \pm 0.00 \mathrm{a}$ & $5.50 \pm 0.31 \mathrm{a}$ & $34.39 \pm 0.37 \mathrm{a}$ \\
& 2.5 & $12.70 \pm 0.22 \mathrm{~h}$ & $100.00(90.00) \pm 0.00 \mathrm{a}$ & $5.57 \pm 0.22 \mathrm{a}$ & $33.90 \pm 0.22 \mathrm{ab}$ \\
& 3.0 & $17.75 \pm 0.30 \mathrm{e}$ & $80.00(63.67) \pm 7.45 \mathrm{~cd}$ & $5.38 \pm 0.18 \mathrm{a}$ & $26.86 \pm 0.18 \mathrm{~h}$ \\
& 3.5 & $22.15 \pm 0.56 \mathrm{c}$ & $73.33(59.20) \pm 9.13 \mathrm{de}$ & $3.92 \pm 0.25 \mathrm{~b}$ & $23.54 \pm 0.26 \mathrm{k}$ \\
& 4.0 & $24.88 \pm 0.39 \mathrm{~b}$ & $63.33(52.79) \pm 7.45 \mathrm{efg}$ & $2.95 \pm 0.37 \mathrm{c}$ & $20.39 \pm 0.501$ \\
& 0.0 & - & $0.00 \mathrm{j}$ & & - \\
& 0.5 & $20.93 \pm 0.38 \mathrm{~d}$ & $36.67(37.21) \pm 7.45 \mathrm{~h}$ & $2.27 \pm 0.25 \mathrm{de}$ & $26.12 \pm 0.40 \mathrm{i}$ \\
& 1.0 & $17.15 \pm 0.36 \mathrm{e}$ & $50.00(45.00) \pm 11.79 \mathrm{gh}$ & $3.88 \pm 0.30 \mathrm{~b}$ & $30.05 \pm 0.19 \mathrm{f}$ \\
& 1.5 & $16.34 \pm 0.40 \mathrm{f}$ & $83.33(68.49) \pm 11.79 \mathrm{bc}$ & $3.89 \pm 0.21 \mathrm{~b}$ & $32.06 \pm 0.11 \mathrm{~d}$ \\
& 2.0 & $15.27 \pm 0.30 \mathrm{~g}$ & $100.00(90.00) \pm 0.00 \mathrm{a}$ & $3.87 \pm 0.14 \mathrm{~b}$ & $33.02 \pm 0.11 \mathrm{c}$ \\
& 2.5 & $16.17 \pm 0.21 \mathrm{f}$ & $89.33(75.05) \pm 9.83 \mathrm{~b}$ & $3.81 \pm 0.41 \mathrm{~b}$ & $32.48 \pm 0.10 \mathrm{~d}$ \\
& 3.0 & $22.16 \pm 0.44 \mathrm{c}$ & $70.00(56.97) \pm 7.45 \mathrm{def}$ & $2.99 \pm 0.39 \mathrm{c}$ & $28.00 \pm 0.20 \mathrm{~g}$ \\
& 3.5 & $25.70 \pm 0.30 \mathrm{a}$ & $56.67(48.89) \pm 9.13 \mathrm{fg}$ & $2.50 \pm 0.17 \mathrm{cde}$ & $25.04 \pm 0.22 \mathrm{j}$ \\
& 4.0 & $26.20 \pm 0.87 \mathrm{a}$ & $40.00(39.16) \pm 9.13 \mathrm{~h}$ & $2.07 \pm 0.38 \mathrm{ef}$ & $23.57 \pm 0.24 \mathrm{k}$ \\
\hline
\end{tabular}

Figures in parentheses are transformed values by the angular transformation before statistical analysis. Means followed by the same alphabet are not significantly different based on DMRT (at $\mathrm{p}<0.01$ ). 
and time taken for rooting were better in half strength MS medium than in full strength MS medium (Figure $4 \mathrm{~A}, \mathrm{C}$ ). The highest values for the time required for root formation, percentage of shoots that produced roots, number of roots and root length were obtained at $2.0 \mathrm{mgL}^{-1}$ IBA concentration with values of 13.07 days, $100 \%, 4.68$ roots and $33.71 \mathrm{~mm}$, respectively (Figure 5 A, B, C). Lowest values in most of the parameters were observed in the medium devoid of IBA $(p<0.01)$. When IBA was used at high concentrations, the time required for root formation was prolonged, number and length of roots were reduced and a large amount of calli was observed at the base of shoots (Figure 5 A, C; Figure 6 $\mathrm{B}, \mathrm{C})$. Interaction of MS and IBA revealed that adding IBA at 2.0 or $2.5 \mathrm{mgL}^{-1}$ to half strength MS medium

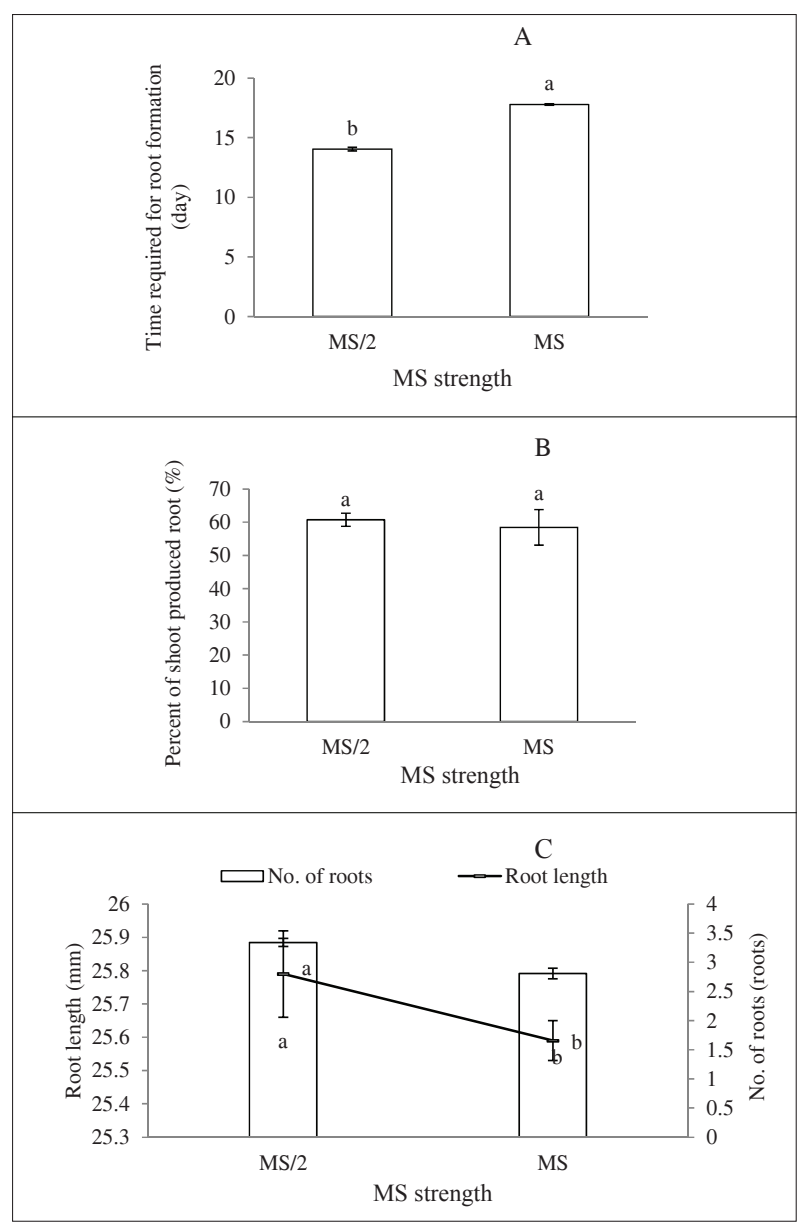

Figure 4: Effect of MS concentration on time required for root formation (A); percentage of shoots that produced roots (B) and no. of roots and root length (C). Different letters at centre bars or right lines show significant differences (DMRT, $\mathrm{p}<0.01$ ). Error bars, or line indicate SE was best for rooting of papaya shoot compared to other combinations (Table 3, Figure $6 \mathrm{~A}$ ). In vitro plantlets grew normally and vigorously in the potting medium containing peat moss : perlite (1:1) after greenhouse acclimation (Figure 7).

It is very difficult to induce a high percentage of rooting as well as produce high-quality adventitious root systems from in vitro shoots of $C$. papaya on an artificial medium (Winnaar, 1988; Drew \& Miller, 1989). There are some complex methods applied for rooting of papaya shoots such as controlling aeration of the medium (Yu et al., 2000) and treatment of shoots in media with PGRs before transferring to a root development medium without hormones (Panjaitan, 2007; Mumo et al., 2013).

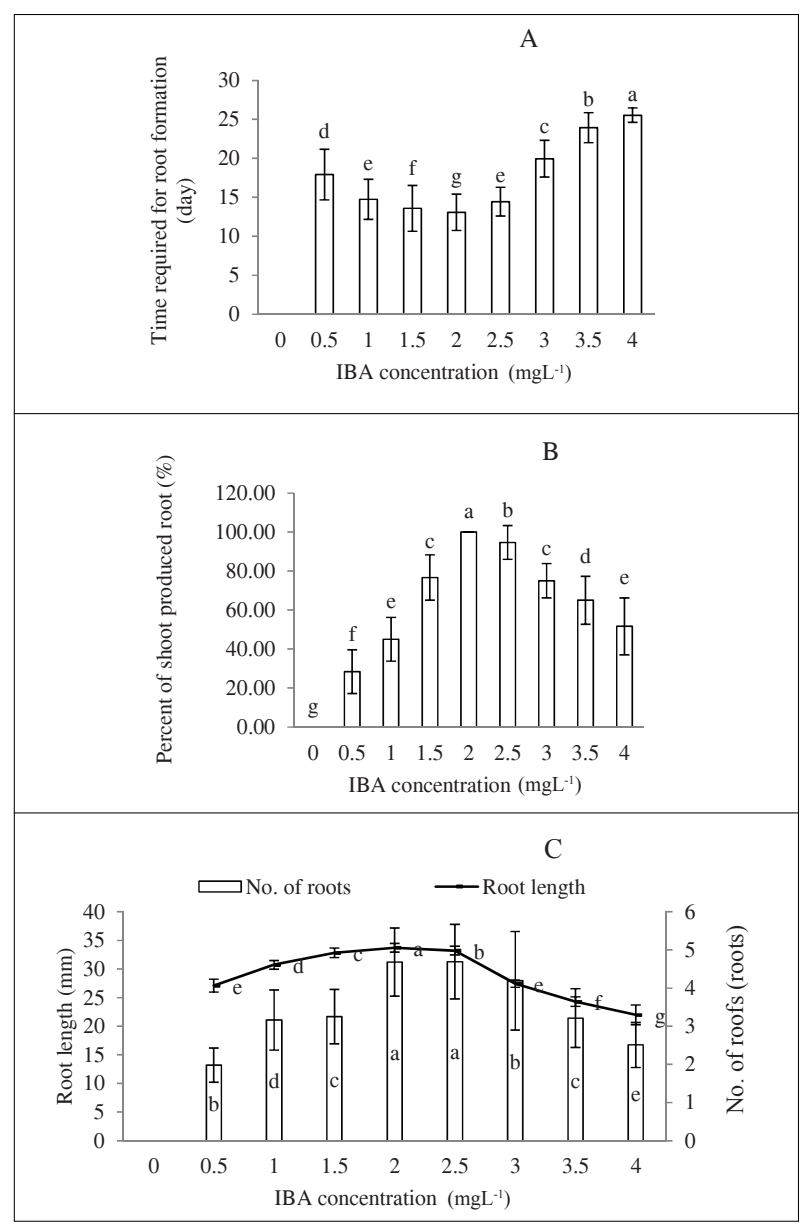

Figure 5: Effect of IBA concentration on time required for root formation (A); percentage of shoots that produced roots (B) and no. of roots and root length (C). Different letters at center bars or right lines show significant differences (DMRT, $\mathrm{p}<0.01$ ). Error bars, or line indicate SE 

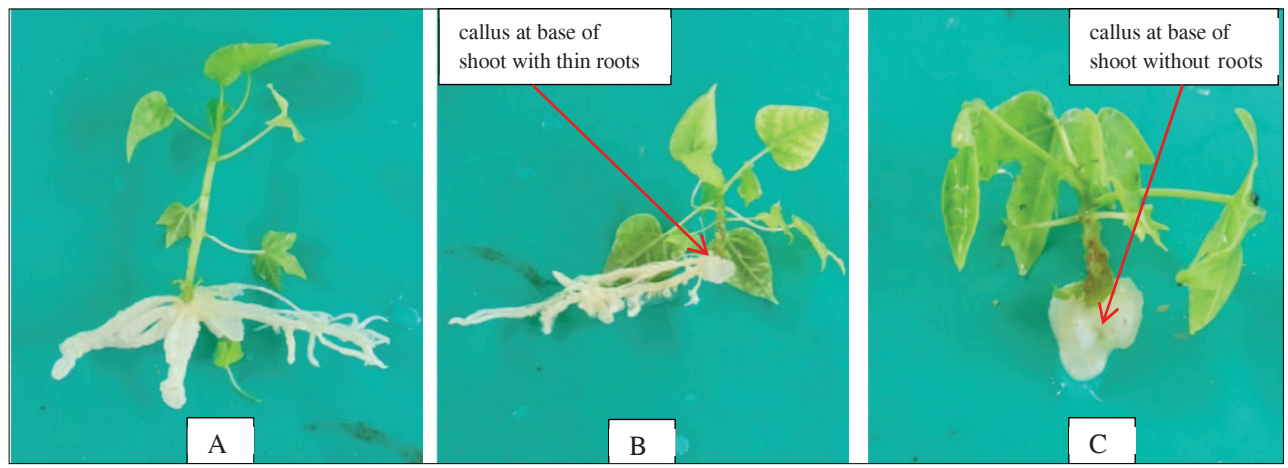

Figure 6: Rooting of micro-shoot in rooting media with $2.0 \mathrm{mgL}^{-1} \mathrm{IBA}(\mathrm{A})$; formation of callus at base of microshoot with thin roots $(\mathrm{B})$ or without roots $(\mathrm{C})$ from rooting media consisting of high IBA concentration

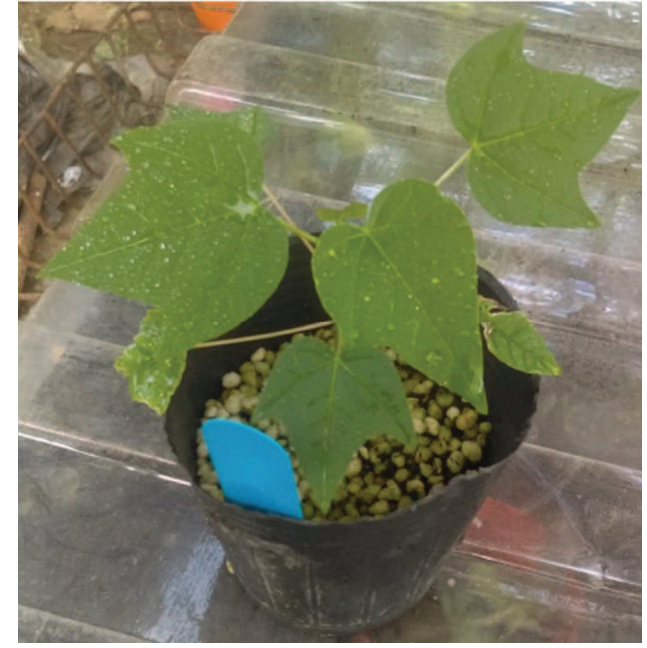

Figure 7: Acclimatised plantlet 40 days after transfer

Many authors adjusted the MS concentration for rooting of shoots and achieved different results. Wu et al. (2012) stated that $3 / 2$ MS (1.5 times the macro-elements of MS) was optimum for root development. Chan and Teo (2002), Kabir et al. (2007) and Ahmed et al. (2007) used full- strength MS as basal rooting medium. Researchers popularly used half-strength macroelements of MS as basal culture medium for rooting micro shoots in papaya (Reuveni et al., 1990; Yu et al., 2000; Rohman et al., 2007; Anandan et al., 2011; Roy et al., 2012; Ambasta \& Kumari, 2013; Setargie et al., 2015). In this study, better results for rooting of shoots were achieved on half-strength MS compared to full-strength MS medium. Adjusting the medium concentration to half-strength MS did not limit shoot growth and resulted in better rooting of shoots compared to full-strength MS. Yu et al. (2000) and Nhan (2004) agreed with this opinion when they tested different MS concentrations (1/4, 1/2, or 1/1 MS).
This may be due to increased root initiation with reduced mineral concentration in the medium (Purohit et al., 1994; Andrade et al., 1999).

The role of auxins such as IBA, or NAA on in vitro rooting of shoots has been well documented (George et al., 2008). IBA had greater ability to promote rooting compared to NAA in micropropagation of papaya (Winnaar, 1988; Roy et al., 2012). Similarly, the present study also showed that IBA was essential for root initiation. Shoots did not form roots on media without IBA. In agreement with the results of Roy et al. (2012), high IBA concentrations produced less number of roots, and calli formation was observed at the base of shoots. According to this study, IBA at $2.0 \mathrm{mgL}^{-1}$ was the optimum concentration for rooting of papaya shoots and similar results were reported by Hidaka et al. (2008), and Ambasta and Kumari (2013). These results were in agreement to those of Setargie et al. (2015) and Mumo et al. (2013), who reported supplementing 1.5 and $2.5 \mathrm{mgL}^{-1} \mathrm{IBA}$, respectively to the rooting medium to obtain optimal rooting. However, some researchers stated that the best results for rooting was achieved at higher concentrations of IBA ( 4 or $5 \mathrm{mgL}^{-1}$ ) (Winnaar, 1988; Roy et al., 2012), whereas Anandan et al. (2011), $\mathrm{Yu}$ et al. (2000) and Mohamad Fhaizal et al. (2006) claimed that the optimal root formation was found at a very low $\left(0.5 \mathrm{mgL}^{-1}\right)$ concentration of IBA. The variation of optimal IBA concentration in root formation endorsed the assumption that different papaya genotypes gave differing responses to PGR.

It has been described that an interaction was observed between IBA and medium concentrations on rooting by Rai et al. (2012) and Hiregoudar et al. (2003). The present study demonstrated that different IBA concentrations significantly affect rooting of 'Red Lady' papaya shoots cultured on half and full-strength MS medium and 2.0 or 
$2.5 \mathrm{mgL}^{-1}$ IBA supplement to $1 / 2 \mathrm{MS}$ medium recorded the best results for growth and rooting of shoots. Similar findings were reported by Ambasta and Kumari (2013) as well as Sekeli et al. (2013).

\section{CONCLUSION}

The present study describes an efficient in vitro technique for the rapid clonal propagation of 'Red Lady' papaya. The protocol describes efficient uses of growth regulators (BAP, kinetin, NAA, IBA), casein hydrolysate $(\mathrm{CH})$ and MS concentrations for shoot regeneration from nodal explant, shoot multiplication and elongation, as well as rooting of in vitro shoots. Shoot regeneration was best under the influence of a combination of 0.5 or $1.0 \mathrm{mgL}^{-1} \mathrm{BAP}$ and $0.1 \mathrm{mgL}^{-1} \mathrm{NAA}$. Combinations of $0.5 \mathrm{mgL}^{-1} \mathrm{BAP}, 0.1 \mathrm{mgL}^{-1} \mathrm{NAA}$ and $200-400 \mathrm{mgL}^{-1} \mathrm{CH}$ were effective for shoot multiplication and elongation. The best rooting response was achieved on half-strength MS medium supplemented with 2.0 or $2.5 \mathrm{mgL}^{-1} \mathrm{IBA}$ and plantlets were successfully acclimatised after 40 days. This successful protocol for micropropagation will contribute to the development of commercial clonal propagation programmes of papaya plants.

\section{REFERENCES}

Ahmed M.B., Salahin M., Karim R., Razvy M.A., Hannan M.M., Sultana R., Hossain M. \& Islam R. (2007). An efficient method for in vitro clonal propagation of a newly introduced sweetener plant (Stevia rebaudiana Bertoni.) in Bangladesh. American-Eurasian Journal of Scientific Research 2: $121-125$.

Ambasta S.K. \& Kumari S. (2013). Efficient procedure for clonal propagation of Carica papaya L. via shoot tip explant. Indian Journal of Plant Science 2: 24 - 33.

Anandan R., Thirugnanakumar S., Sudhakar D. \& Balasubramanian P. (2011). In vitro organogenesis and plantlet regeneration of Carica papaya L. Journal of Agricultural Technology 7: 1339 - 1348.

Andrade L.B., Echeverrigaray S., Fracaro F., Pauletti G.F. \& Rota L. (1999). The effect of growth regulators on shoot propagation and rooting of common lavender (Lavandula vera DC). Plant Cell, Tissue and Organ Culture 56: 79 - 83. DOI: https://doi.org/10.1023/A:1006299410052

Ascencio-Cabral A., Gutiérrez-Pulido H., Rodríguez-Garay B. \& Gutiérrez-Mora A. (2008). Plant regeneration of Carica papaya L. through somatic embryogenesis in response to light quality, gelling agent and phloridzin. Scientia Horticulturae 118: 155 - 160. DOI: https://doi.org/10.1016/j.scienta.2008.06.014

Chan L.K. \& Teo C.K.H. (1994). Culture of papaya explant in solid - liquid media sequence as a rapid method for producing multiple shoots. Pertanika Journal of Tropical Agricultural Science 17: 103 - 106.

Chan L.K. \& Teo C.K.H. (2002). Micropropagation of Eksotika, a Malaysian papaya cultivar, and the field performance of the tissue culture derived clones. Acta Horticulturae 575: $99-105$.

DOI: https://doi.org/10.17660/ActaHortic.2002.575.8

Chaturvedi R., Razdan M.K. \& Bhojwani S.S. (2004). In vitro clonal propagation of an adult tree of neem (Azadirachta indica A. Juss.) by forced axillary branching. Plant Science 166: $501-506$.

DOI: https://doi.org/10.1016/j.plantsci.2003.10.021

Chong S.T., Prabhakaran R. \& Lee H.K. (2008). An improved technique of propagating 'Eksotika' papaya. Acta Horticulturae 787: 273 - 276.

DOI: https://doi.org/10.17660/ActaHortic.2008.787.30

Clarindo W.R., de Carvalho C.R., Araujo F.S., de Abreu I.S. \& Otoni W.C. (2008). Recovering polyploid papaya in vitro regenerants as screened by flow cytometry. Plant Cell, Tissue and Organ Culture 92: 207 - 214.

DOI: https://doi.org/10.1007/s11240-007-9325-1

Cohen D. \& Cooper P.A. (1982). Micropropagation of babaco - a Carica hybrid from Ecuador. Proceedings of the $5^{\text {th }}$ International Congress of the Plant Tissue Cell Culture (ed. A. Jujiwara), Tokyo, Japan, pp. $743-744$.

Drew R.A. \& Miller R.M. (1989). Nutritional and cultural factors affecting rooting of papaya (Carica papaya L.) in vitro. Journal of Horticultural Science 64: 767 - 773. DOI: https://doi.org/10.1080/14620316.1989.11516019

Farzana A.R.F., Palkadapala P.G.V.N., Meddegoda K.M.M.N., Samaraijeewa P.K. \& Eeswara J.P. (2008). Somatic embryogenesis in papaya (Carica papaya L. cv. Rathna). Journal of the National Science Foundation of Sri Lanka 36: $41-50$.

DOI: https://doi.org/10.4038/jnsfsr.v36i1.132

Gao H.H., Li W., Yang J., Wang Y., Gua G.Q. \& Zheng G.C. (2003). Effect of 6-benzyladenine and casein hydrolysate on micropropagation of Amorpha fruiticosa. Biologia Plantarum 47: 145 - 148.

DOI: https://doi.org/10.1023/A:1027361721860

George E.F. \& De Klerk G.J. (2008). The components of plant tissue culture media I: macro and micro nutrients. Plant Propagation by Tissue Culture, $3^{\text {rd }}$ edition (eds. E.F. George, M.A. Hall \& G.J. De Klerk), pp. 65 - 113. Springer Netherlands. Originally published by Exegetics, Basingstoke, UK.

Hidaka T., Komori S., Yamada M. \& Fukamachi H. (2008). Mass-production of papaya (Carica papaya L.) samplings using shoot-tip culture for commercial use. South Pacific Studies 28: 87 - 95 .

Hiregoudar L.V., Murthy H.N., Hema B.P., Hahn E.J. \& Paek K.Y. (2003). Multiple shoot induction and plant regeneration of Feronia limonia (L.) Swingle. Scientia Horticulturae 98: 357 - 364.

Hosny S.M., Hammad G., Sharbasy S.E. \& Zayed Z. (2016). Effect of coconut milk, casein hydrolysate and yeast extract on the proliferation of in vitro barhi date palm (Phoenix dactylifera L.). Journal of Horticultural Science and Ornamental Plants 8: 46 - 54.

Jabeen N., Chaudhry Z., Rashid H. \& Mirzaa B. (2005). Effect of genotype and explants type on in vitro shoot regeneration of tomato (Lycopersicon esculantum Mill.). Pakistan Journal of Botany 37: 899 - 903. 
Jordan M., Cortes I. \& Montenegro G. (1983). Regeneration of plants by embryogenesis from callus cultures of Carica candamarcensis. Plant Science Letters 28: 321 - 326.

Kabir A.H., Bari M.A., Huda A.K.M.N., Rezvy M.A. \& Mahfuz I. (2007). Effect of growth regulators and carbon sources on axillary shoot proliferation from shoot-tip explant and successful transplantation of papaya (Carica papaya L.). Biotechnology 6: 268 - 272.

DOI: https://doi.org/10.3923/biotech.2007.268.272

Machakova I., Zazimalova E. \& George E.F. (2008). Plant growth regulators I: introduction; auxins, their analogues and inhibitors. Plant Propagation by Tissue Culture, $3^{\text {rd }}$ edition (eds. E.F. George, M.A. Hall \& G.J. De Klerk), pp. 175 - 204. Springer Netherlands. Originally published by Exegetics, Basingstoke, UK.

Mohamad Fhaizal M.B., Pillai V., Rahman N. \& Khalid N. (2006). Effect of carbenicillin on somatic embryos formation of papaya (Carica papaya L. var Eksotika I). Malaysian Journal of Science 25: 47 - 54.

Mumo N.N., Rimberia F.K., Mamati G.E. \& Kihurani A.W. (2013). In vitro regeneration of selected Kenyan papaya (Carica papaya L.) lines through shoot tip culture. African Journal of Biotechnology 12: 6826 - 6832.

Murashige T. \& Skoog F. (1962). A revised medium for rapid growth and bioassays with tobacco tissue cultures. Physiologia Plantarum 15: 473 - 497.

DOI: https://doi.org/10.1111/j.1399-3054.1962.tb08052.x

Nhan N.T. (2004). Use of in-vitro culture for rapid propagation of papaya (Carica papaya L.). Vietnamese Journal of Agricultural Science 2: 174 - 180.

Panjaitan S.B., Aziz M.A., Rashid A.A. \& Saleh N.M. (2007). In vitro plantlet regeneration from shoot tip of field-grown hermaphrodite papaya (Carica papaya L. Cv. Eksotika). International Journal of Agriculture and Biology 6: $827-832$.

Paull R.E. \& Duarte O. (2011). Papaya. Tropical Fruits. (Crop Production Science in Horticulture) (eds. S. Hulbert \& S. Wilford), pp. 291 - 326. CABI International, London, UK.

Prakash S., Agrawal V. \& Gupta S.C. (2003). Influence of some adjuvants on in vitro clonal propagation of male and female jojoba plants. In vitro Cellular and Developmental Biology - Plant 39: 217 - 222.

DOI: https://doi.org/10.1079/IVP2002369

Purohit S.D., Dave A. \& Kukda G. (1994). Micropropagation of safed musli (Chlorophytum borivilianum), a rare Indian medicinal herb. Plant Cell, Tissue and Organ Culture 39: $93-96$.

DOI: https://doi.org/10.1007/BF00037596

Rai G.K., Singh M., Rai N.P., Bhardwaj D.R. \& Kumar S. (2012). In vitro propagation of spine gourd (Momordica dioica Roxb.) and assessment of genetic fidelity of micropropagated plants using RAPD analysis. Physiology and Molecular Biology of Plants 18(3): 273 - 280.

DOI: https://doi.org/10.1007/s12298-012-0109-7

Ramkhelawan E. \& Baksh N. (1998). Vegetative propagation of papaya (Carica papaya L.) in Trinidad. TFNet Newsletter 29: $9-11$.

Reuveni O., Shlesinger D.R. \& Lavi U. (1990). In vitro clonal propagation of dioecious Carica papaya. Plant Cell, Tissue and Organ Culture 20(1): $41-46$.

DOI: https://doi.org/10.1007/BF00034755

Rohman M.M., Islam M.N., Alam M.S., Ahmad M.R. \& Paul T.K. (2007). Lateral bud culture of papaya (Carica papaya) for clonal propagation. Biotechnology 6: 339 - 343 . DOI: https://doi.org/10.3923/biotech.2007.339.343

Roy P.K., Roy S.K. \& Hakim M.D.L. (2012). Propagation of papaya (Carica papaya L.) Cv. Shahi. Bangladesh Journal of Botany 41: 191 - 195.

San Jose A.R. \& Marim S.L.D. (1988). Propagation of papaya. Brazilian Symposium on Papaya Culture. Jaboticabal: FUNEP.

Sekeli R., Abdullah J.O., Namasivayam P., Muda P. \& Bakar U.K.A. (2013). Better rooting procedures to enhance survival rate of field grown Malaysian Eksotika papaya transformed with 1-aminocyclopropane-1carboxylic acid oxidase gene. International Scholarly Research Notices: Biotechnology 2013: Article ID 958945.

Setargie A., Mekbib F. \& Abraha E. (2015). In vitro propagation of papaya (Carica papaya L.). World Journal of Agricultural Sciences 11: $84-88$.

Skoog F. \& Miller C.O. (1957). Chemical regulation of growth and organ formation in plant tissues cultured in vitro. Symposia of the Society for Experimental Biology 11: $118-130$.

Sridhar T.M. \& Aswath C.R. (2014). Influence of additives on enhanced in vitro shoot multiplication of Stevia rebaudiana (Bert.)-an important anti diabetic medicinal plant. American Journal of Plant Sciences 5: 192 - 199.

Suksa-Ard P., Kataoka I., Beppu K., Fujine Y. \& Subhadrabandhu S. (1997). Hormonal and nutritional factors affecting shoot growth of papaya in vitro. Technical Bulletin of Faculty of Agriculture, Kagawa University 49: $165-170$.

Sultana R.S. \& Bari Miah M.A. (2003). In vitro propagation of Karalla (Momordica charantea Linn.) from nodal segment and shoot-tip. Journal of Biological Sciences 3(12): $1134-1139$. DOI: https://doi.org/10.3923/jbs.2003.1134.1139

Teixeira da Silva J.A., Rashid Z., Nhut D.T., Dharini S., Abed G., Manoel T.S.J. \& Paula F.T. (2007). Papaya (Carica papaya L.) biology and biotechnology. Tree and Forestry Science and Biotechnology 1: 47 - 73.

Usman M., Fatima B., Khan M.M. \& Khan I.A. (2002). Response of reproductive organs of papaya to callogenesis. Pakistan Journal of Agricultural Sciences 39: 210 - 216.

Winnaar W.D. (1988). Clonal propagation of papaya in vitro. Plant Cell, Tissue and Organ Culture 12: 305 - 310. DOI: https://doi.org/10.1007/BF00034373

Wu K., Zeng S., Chen Z. \& Duan J. (2012). In vitro mass propagation of hermaphroditic Carica papaya CV. Meizhonghong. Pakistan Journal of Botany 44(5): 1669 - 1676.

Yu T.A., Yeh S.D., Cheng Y.H. \& Yang J.S. (2000). Efficient rooting for establishment of papaya plantlets by micropropagation. Plant Cell, Tissue and Organ Culture 61: $29-35$.

DOI: https://doi.org/10.1023/A:1006475901439 